\title{
Parent Perspectives on CLIL Implementation: Which Variables Make a Difference?
}

\author{
JUAN RÁEZ-PADILLA \\ University of Jaén
}

Received: 19 June 2017 / Accepted: 3 October 2017

ISSN: 1697-7467

\begin{abstract}
This article canvasses parents' outlooks on CLIL program development. To this end, it has applied questionnaires to 237 parents in the western Andalusian provinces of Cádiz and Málaga in order to carry out an in-depth analysis of this cohort's perspectives on CLIL implementation. After framing the topic against the backdrop of prior investigations and substantiating the need for a study of this nature, the article expounds on its research design and outlines its main findings in relation to the seven main fields of interest which have been canvassed: L2 competence development, methodology, materials and resources, evaluation, training and information, mobility, and improvement and motivation towards English, including and overall appraisal of bilingual programs. A detailed diagnosis of where we currently stand in this process of implementation of CLIL pedagogy is provided and within-cohort comparisons are carried out in terms of a series of intervening variables.
\end{abstract}

Keywords: CLIL, program evaluation, intervening variables, parent perspectives

Perspectivas parentales sobre la implementación de AICLE: ¿Qué variables marcan la diferencia?

RESUMEN: El presente artículo sondea el punto de vista de los padres en relación con el desarrollo de programas AICLE. Para ello, se han aplicado cuestionarios a 237 padres en las provincias andaluzas occidentales de Cádiz y Málaga con el objetivo de llevar a cabo un análisis exhaustivo de su opinión sobre la implementación de programas AICLE. Tras inscribir el estudio en el marco de investigaciones previas y justificar la necesidad de investigaciones de esta naturaleza, en el artículo se expone el diseño de investigación llevado a cabo y se resumen sus principales hallazgos en relación con siete campos de interés sondeados: el desarrollo de la competencia L2, metodología, materiales y recursos, evaluación, formación e información, movilidad y mejora y motivación en inglés, incluyendo una valoración global de programas bilingües. Se proporciona asimismo un diagnóstico detallado sobre el lugar donde nos encontramos en relación con este proceso de implementación de pedagogías AICLE, y se establecen comparaciones dentro de la cohorte considerando una serie de variables.

Palabras clave: AICLE, evaluación de programas, variables, punto de vista parental 


\section{Introduction: A theoretical OVERVIEW}

During the past two decades, great expectations have been placed on CLIL (Content and Language Integrated Learning $)^{1}$ with a view to fostering plurilingualism in the European education arena. As for Spain, and more particularly the southern autonomous community of Andalusia, CLIL has come to the fore as a stepping stone to achieve this goal at Primary and Secondary education. This new shift towards bilingual education is in consonance with the European Higher Education Area, which lays an emphasis on innovative methods, student-centered pedagogies and lifelong learning ingrained in the very teaching process. This shift has been channeled via two groundbreaking documents whose institutional theoretical foundations have trickled down to the teaching practice in plurilingual education at Andalusia: the Andalusian Plan for the Promotion of Plurilingualism (Plan de Fomento del Plurilingüismo; henceforth, APPP) (Junta de Andalucía, 2005) and the Strategic Plan for the Development of Languages in Andalusia (Plan Estratégico de Desarrollo de las Lenguas en Andalucia; henceforth, PEDLA) (Junta de Andalucía, 2017).

Specialized literature with a theoretical perspective is abundant as regards the potential benefits of CLIL and student-centered methodologies in the classroom (Banegas, 2012; Brüning \& Purrmann, 2014; Coyle, 2010; Cummins, 2000; Jäppinen, 2006; Lorenzo, 2007; Marsh et al., 2001; Michavila, 2009; Pavón Vázquez \& Rubio, 2010; Pérez Cañado, 2012, 2015; Wolff, 2002), which should thus transcend the monolithic monolingual tradition and provide for a new pioneering plurilingual stance. The process to such an ideal implementation in the Andalusian classes has not always been easy, and controversy and "upheavals" (Lorenzo, 2010: 4) have been reported in such a daunting enterprise. It thus goes without saying that whether CLIL postulates are actually being implemented on the Andalusian education arena or not needs to be scrutinized. As a matter of fact, not all the different groups concerned in education (students, teachers and parents) have homogeneous views about CLIL and how it is being implemented in Andalusia. Cabezas Cabello warns, for example, that "There are discrepancies between educational policies and real teaching contexts" (2010: 86), and that on many occasions lip service has been paid to the student-centered methodologies allegedly implemented through CLIL practice (2010: 90). Likewise, Breidbach \& Viebrock (2012: 12) also denounce that CLIL's highly innovative potential requires a conscious, active use on the part of teachers, for this innovation "does not happen automatically".

Among the different groups under scope in the present thematic issue, this article addresses parent perspectives on the actual implementation of CLIL methodologies, materials, and evaluation in the aforementioned monolingual context. It works with a representative sample of 237 parents from the western Andalusian provinces of Cádiz and Málaga, and the administered questionnaires can be found in Pérez Cañado (2016b). ${ }^{2}$ After discussing

\footnotetext{
${ }^{1}$ CLIL is a dual-focussed education approach in which "students both learn a language and learn other subjects, or parts of subjects, through languages other than the first language. This requires adaptation of teaching and learning methodologies, particularly if these have been originally developed for monolingual education. The purpose-designed methodological approach, specifically for students learning content through an additional language, is called Content and Language Integrated Learning (CLIL)" (Marsh, 2015: 190).

${ }^{2}$ Available at $<$ http://revistas.cardenalcisneros.es/index.php/PULSO/article/view/217 $>$ [Accessed 01/06/2017].
} 
the research design, findings will be provided descriptively and by drawing within-cohort comparisons, in relation to the seven main fields of interest which have been canvassed: L2 competence development, methodology, materials and resources, evaluation, training and information, mobility, and improvement and motivation towards English, including an overall appraisal of bilingual programs. The chapter will conclude by drawing the main qualitative conclusions extracted from the quantitative figures and triangulation.

This article stems from the premise that parents, together with students and teachers, are key players in CLIL implementation, so that canvassing their opinions can help to shed light upon some of the controversies affecting CLIL characterization, among which vagueness, ambiguity or heterogeneous methodologies have been adduced (Bruton, 2013; Cenoz et al., 2013; Czura \& Papaja, 2013; Liberali, 2013; Paran, 2013). Notwithstanding this, an exponential uptake has been witnessed in the past half a decade, to which parents have also contributed, for it has been "embraced quickly and enthusiastically by stakeholders: parents, students, language/educational policy-makers" (emph. is mine) (Lasagabaster \& Doiz, 2016, p. 1). So as to assuage that alleged indeterminacy, calls have recently been made for the "development of a CLIL-specific didactic and methodology" (Brüning \& Purrmann, 2014: 335), for establishing "clear [...] criteria" and "uniform aims" (Czura \& Papaja, 2013: 332), and for characterizing "representative pedagogical practices" (Bruton, 2011: 254) in order to allow the CLIL agenda to continue advancing strongly and steadily. In the answer to such a conundrum, parents may offer an informative, mid-way view about the possible discrepancies between teachers and students, theory and practice, when it comes to implementing CLIL in the classroom. In fact, they have been considered in other studies (for example, Casal and Moore, 2008; Lorenzo, Casal \& Moore, 2009; Lorenzo, Casal, Moore \& Afonso, 2009, in Andalusia; or Mehisto \& Asser, 2007, in Northern Europe), and they are active agents in some of the subprograms into which the aforementioned APPP is fleshed out: thus, the Bilingual Schools Program includes, among other measures, training for parents, whereas one of the actions encompassed in the so-called Plurilingualism and Society strand is an increase in FL learning for parents and adults (Junta de Andalucía, 2005). In this overarching endeavour that the present study seeks to contribute to, parents do have a say, and their feedback, hereby analysed, can provide valuable perspectives from which to adjust and qualify the present Andalusian CLIL agenda.

\section{The STUdY}

\subsection{Objectives}

The main objective of this study is to evaluate parent perspectives of the present state of CLIL programs in Andalusia in consideration of L2 competence development, methodology, materials and resources, evaluation, training and information, mobility, and improvement and motivation towards English. It polls parent perceptions of the way in which CLIL programs are being implemented in the aforementioned region, which has traditionally been rooted in a monolingual tradition. Two key metaconcerns, which are fleshed out below in different components, have driven the present study and the project as a whole: 
Metaconcern 1 (Needs analysis)

1. To determine parent perceptions vis-à-vis students' L2 competence development in CLIL classes at Primary and Secondary education.

2. To determine parent perceptions of the type of methodology which is being implemented in CLIL classes at Primary and Secondary education.

3. To determine parent perceptions of the type of materials and resources which are being employed in CLIL classes at Primary and Secondary education.

4. To determine parent perceptions of the type of evaluation which is being carried out in CLIL classes at Primary and Secondary education.

5. To determine parent perceptions as regards teachers' training and their own information about CLIL classes at Primary and Secondary education.

6. To determine parent perceptions of the main mobility needs required by students in CLIL classes at Primary and Secondary education.

7. To determine parent perceptions of students' improvement, as well as motivation towards English for students and parents alike, in CLIL classes at Primary and Secondary education.

\section{Metaconcern 2 (Within-cohort comparison)}

8. To determine if there are statistically significant differences vis-à-vis CLIL program development within the cohort of parents in terms of their offspring education level (Primary or Secondary), age, gender, and level of completed studies.

\subsection{Research design}

The present investigation is an example of primary research, and more precisely of survey research, for it includes questionnaires (Brown, 2001). Survey research is typically data-based, employs questionnaires, and includes both qualitative and statistical methods for the interpretation of the feedback obtained from those questionnaires. Our study has also made use of what Denzin (1970) terms multiple triangulation, specifically of location triangulation, considering that data has been collected from more than one context: Primary and Secondary schools.

\subsection{Sample}

The project has worked with an ample cohort of parents in the autonomous community in question (in particular, from the Andalusian provinces of Cádiz and Málaga). The overall study has had a significant return rate, as the questionnaires have been conducted with a total of 237 informants. The most representative cohort has been that of Secondary education, with 152 participants (64.1\%), while that of Primary education scores second, with 85 participants $(35.9 \%$ ) (cf. Figure 1). In terms of gender, women (66.8\%) significantly outnumber their male counterparts (33.2\%) (cf. Figure 2). 


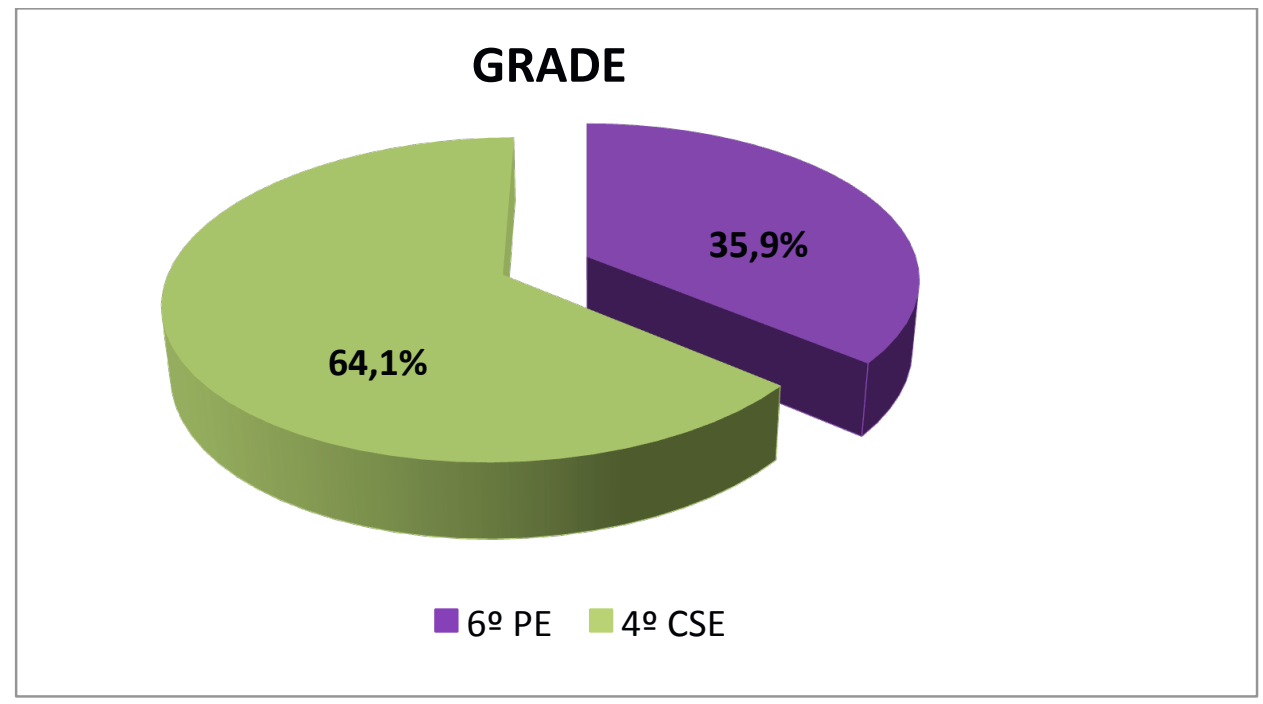

Figure 1. Breakdown of the overall sample in terms of offspring education level

\section{GENDER}

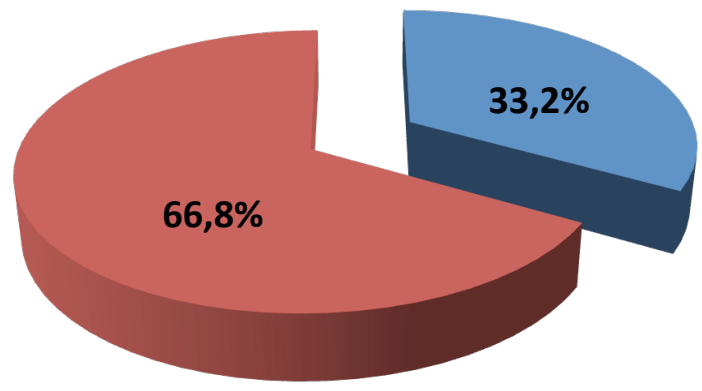

Male Female

Figure 2. Breakdown of the overall sample in terms of gender 
Roughly equal percentages of parents are 45 or younger $(49.6 \%)$ or older than 45 $(50.4 \%)$. The vast majority of them have Spanish nationality $(97.5 \%)$, with only residual percentages of European (0.4\%), Latin American (0.4\%) and other (0.4\%) nationalities. As for the level of completed studies, there are similar percentages of parents having completed a 4-year university Degree (21.9\%), Primary Education (20.3\%), a 3-year university Degree $(19 \%)$ or a professional training Diploma (17.7\%), while a significantly smaller amount of parents have no qualifications at all (6.3\%), Secondary Education $(5.5 \%)$, or PhD studies $(2.5 \%)$. Grouping these figures considering the different education levels, $6.3 \%$ of parents have no studies at all, 20.3\% have completed Primary Education, 23.2\% Secondary Education and $43.4 \%$ Tertiary Education.

\subsection{Variables}

A series of identification (subject) variables have been considered, related to the individual characteristics of the stakeholders who have been polled through the questionnaire. The identification variables for the parent cohort are specified below:

- Offspring education level (Primary or Secondary)

- Age

- Gender

- Nationality

- Level of completed studies.

\subsection{Instruments}

The study has made use of self-administered questionnaires, which Brown (2001) identifies within survey tools. Three sets of questionnaires (one for each of the overall cohorts: teachers, students, and parents) have been designed and validated in both Spanish and English for the overall project. They include, using Patton's (1987) terminology for question types, demographic or background questions to elicit biographical information from the participants (which correspond to the identification variables) and opinion or value questions to look into stakeholder perceptions regarding CLIL program development. The latter questions are exemplified in the form of 40 items within the parent questionnaire.

For the validation of the questionnaires, a double-fold pilot procedure has been implemented, which comprised a first stage in which experts provided their ratings, and an ensuing second pilot phase with a representative sample of respondents (263 informants). Their responses allowed us to refine the questionnaires and avoid ambiguities and redundancies; in turn, they also enabled the calculation of Cronbach alpha for each of the surveys in order to guarantee their reliability or internal consistency. The latter was achieved by means of the outstanding high coefficients obtained for the questionnaires: 0.940 for the student one, 0.931 for the teacher equivalent, and 0.895 for the parent survey (cf. Pérez Cañado, 2016b for a detailed rendering of the design and validation of the questionnaires and to access to the final versions for each of the three cohorts). 


\subsection{Data analysis: Statistical methodology}

The data obtained on the questionnaires have been analyzed statistically, using the SPSS program in its 21.0 version. Descriptive statistics have been used to interpret the results obtained for metaconcern 1 (objectives 1-7). Both central tendency (mean, median and mode) and dispersion measures (range, low-high, standard deviation) have been calculated. As for metaconcern 2 (objective 8), the ANOVA, t test and Mann-Whitney $U$ test have been employed to discriminate whether there are statistically significant differences within the group in consideration of the different moderating and identification variables.

\section{Results AND Discussion}

\subsection{Program evaluation}

Under the scope of the first metaconcern (objectives 1-6), our study has allowed us to evaluate parent perspectives of the main curricular and organizational aspects of CLIL programs within our monolingual context. Regarding the students' L2 competence development, the parents reported that CLIL programs have exerted a positive influence on their offspring's English level and understanding of how their mother tongue and foreign language interrelate (items 1 and 5). This was one of the main objectives of the APPP (cf. section 1), which thus seems to have been achieved, according to the parents polled in our survey. They also contend that the bilingual program has positively impacted on the students' knowledge of the subject contents, confidence, and oral, written, and intercultural competence in English (items $3,6,7,8$, and 9), also correlating with the assumption that learning contents in English is not more difficult than in Spanish (item 4). Curiously enough, the only item scoring below 3 (2.75) is assuming that their level of Spanish has improved because of the participation in the bilingual program (item 2).

Similarly to the most recent findings about methodology (Lancaster, 2016; Pérez Cañado, 2016a, 2016c), a consolidation is ascertained in the use of innovative and student-centered methodologies (item 11, 2.99/4). Moreover, parents offer a positive picture as regards the acquisition of vocabulary (item 10,3.27/4), so that according to this the Lexical Approach ${ }^{3}$ would be yielding positive results. Parents do not agree, though, on being able to help their offspring with their homework in the bilingual program (item 12, $2.43 / 4$ ), which outstands as the main niche to be filled on with regard to methodological aspects (cf. Figure 3).

${ }^{3}$ The Lexical Approach was introduced by Michael Lewis (1993). It upholds in foreign language teaching that in order to successfully learn a language, the speaker should understand and produce lexical phrases as chunks, focussing on fixed expressions of real English which are typically used in native contexts. 


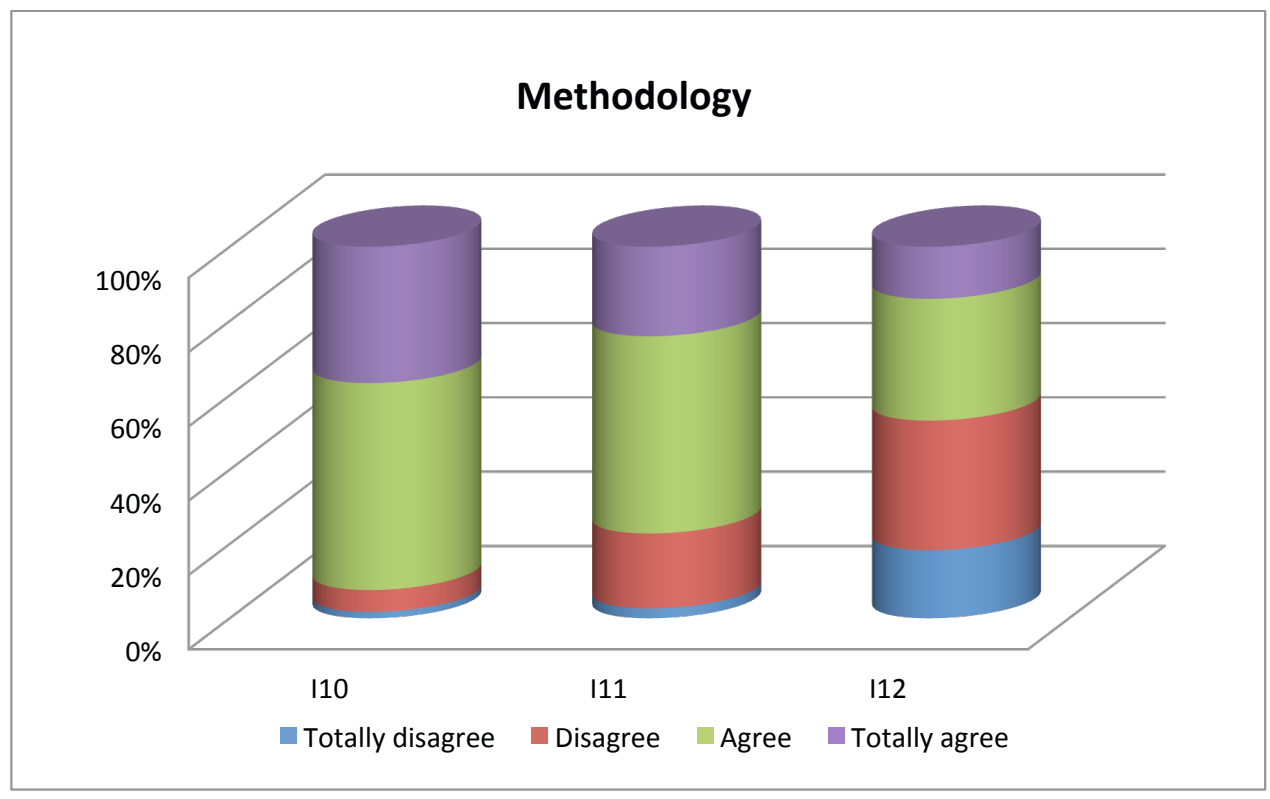

Figure 3. Percentage of parent perspectives on each of the items considered (10-12) in methodology

As for materials and resources, parents are positive but not overenthusiastic about their being interesting, innovative (item 13, 2.74/4), or communicative (item 14, 2.88/4), and only a lukewarm response is shown towards materials adaptation (item 15, 2.74/4) or the use of new technologies in the bilingual program (item 16, 2.92/4). The results from item 15 corroborate an important lacuna evinced by other authors (Cabezas Cabello, 2010; Lancaster, 2016). On the technological front at stake in item 16, our findings coincide with those of the latest investigations (Lancaster, 2016; Pérez Cañado, 2016a, 2016c), which emphasize that certain technological aspects still require heightened attention, in line, again, with one of the chief lines of action of the PEDLA in Andalusia. Parents do not think that the materials for the bilingual education are necessarily more expensive (item 18, 2.43/4), and again partially positive answers were obtained with regard to the exposure to the English language outside school (item 19, 2.65/4), or the available extramural materials (item 20, 2.91/4). In line with the findings about methodology above, the lowest score is assigned to the available guidelines in Spanish for parents to help their offspring at home (item 18, $2.32 / 4$ ), which proves that further action should be taken on this front so as to make parents feel empowered to participate in their children's bilingual education.

Positive steps appear to have been taken with respect to evaluation. According to parents, the features which are theoretically associated to student-centered evaluation are actually being incorporated into CLIL classroom practice, as they respond that evaluation is adequate (item 21,3.04/4); exams are regularly taken with a view to implementing diversified, ongoing, holistic evaluation (item 22, 3.18); a more oral approach is considered to run 
through evaluation (item 23, 3.13); contents are awarded a certain priority over linguistic accuracy (item 24, 2.79); and better results were achieved thanks to the implementation of the bilingual program (item $25,3.2 / 4$ ), something which was not always the case in prior studies (e.g. Lancaster, 2016) (cf. Figure 4).

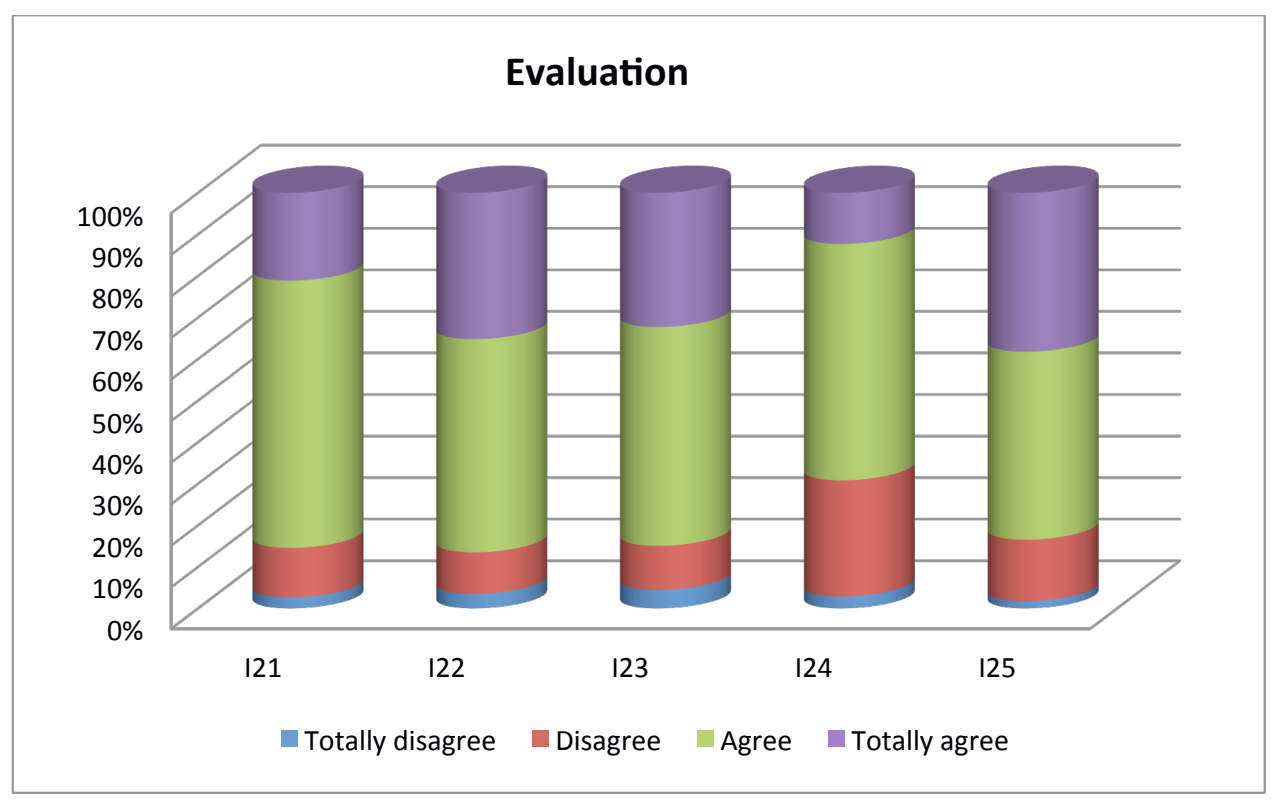

Figure 4. Percentage of parent perspectives on each of the items considered (21-25) in evaluation

An outstanding contrast is perceived between teacher training and parents' information about the bilingual program. Whereas all means concerning teacher training are above 3 , the items concerning parents' information are all below 3 . Thus, parents think that teachers are proficient in English in both the oral (item 26, 3.33/4) and written skills (item 27, 3.35/4), and have an adequate intercultural competence (item 28, 3.29/4). And while parents' information about the bilingual program in the school is relatively sufficient (item 29, 2.98/4), they adduce some information gap in the institutional and theoretical macro contexts, namely in the basic principles of CLIL (item 31, 2.58/4), and, especially, in the APPP (item 30, 2.43/4) (cf. Figure 5). This alleged lack of information points towards the same lack of confidence and guidance in Spanish manifested in methodology and resources above, which may well merit further reflection and consideration for a success-prone implementation of CLIL programs in Andalusia, given the importance which parents' involvement and extramural assistance to their children have in guaranteeing such success. 


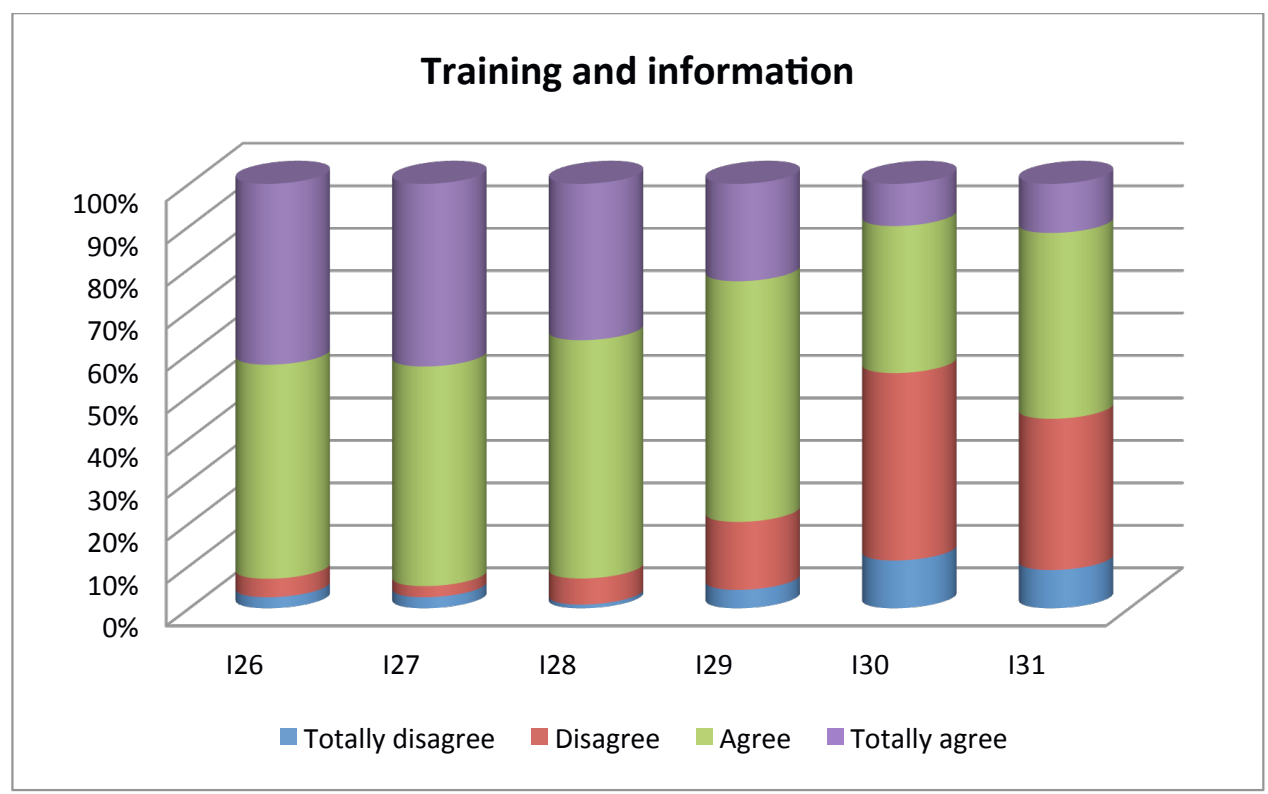

Figure 5. Percentage of parent perspectives on each of the items considered (26-31) in teachers' training and parents' information

A very interesting contrast is found between the theoretical importance ascribed to mobility in bilingual programs and the number of families in which mobility is actually accomplished. Thus, while parents report that participating in exchange/linguistic programs can be beneficial for their children (item 33,3.43/4), or that they motivate their offspring to participate in such programs (item $34,3.32 / 4$ ), a much lower mean (item 32, 2.23/4) is scored when it comes to confirming that this mobility was actually put into practice (cf. Figure 6). This is also an area for further consideration in the overarching Andalusian bilingual program, and one which may well foster further research so as to discern whether economic, organizational, motivational, emotional or other type of reasons are to be considered for such inconsistency. 


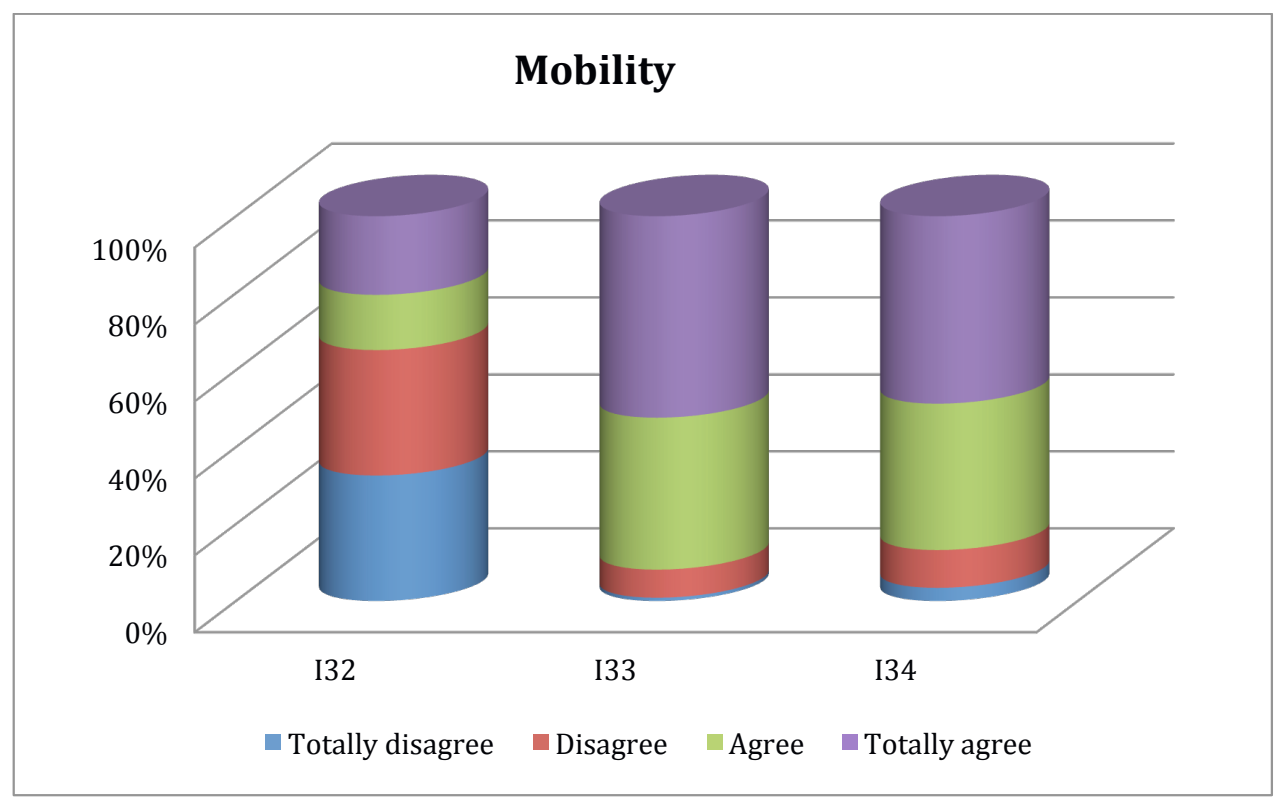

Figure 6. Percentage of parent perspectives on each of the items considered (32-34) in mobility

Finally, when it comes to registering the improvement and motivation triggered by the program, which in general terms can be evinced, there is again a slight mismatch if general opinion about the CLIL program and that which applies to the students is compared with self-opinions of parents. Thus, the overall assessment is very positive (item 40,3.49/4), and parents think their children's belonging to a bilingual group does indeed compensate for the increase in workload (item 35, 3.35/4). As for their view about the students themselves, parents register a general improvement in the English language (item 36, 3.37/4) and motivation (item $38,3.33 / 4$ ) thanks to the bilingual program. Parents are less positive (with means below 3/4) about their own motivation (item 37, 2.85/4), and from their responses it is ascertained that the frequency with which they communicate with teachers to check their children's progress could be further improved (item 39, 2.66/4) (cf. Figure 7). As can be seen, again the variables which have to do with self-motivation and communication with teachers show that, even though they are not strictly speaking negative, a more solid involvement on the part of the parents would be desirable if compared with other agents (teachers and students) within the bilingual program. 


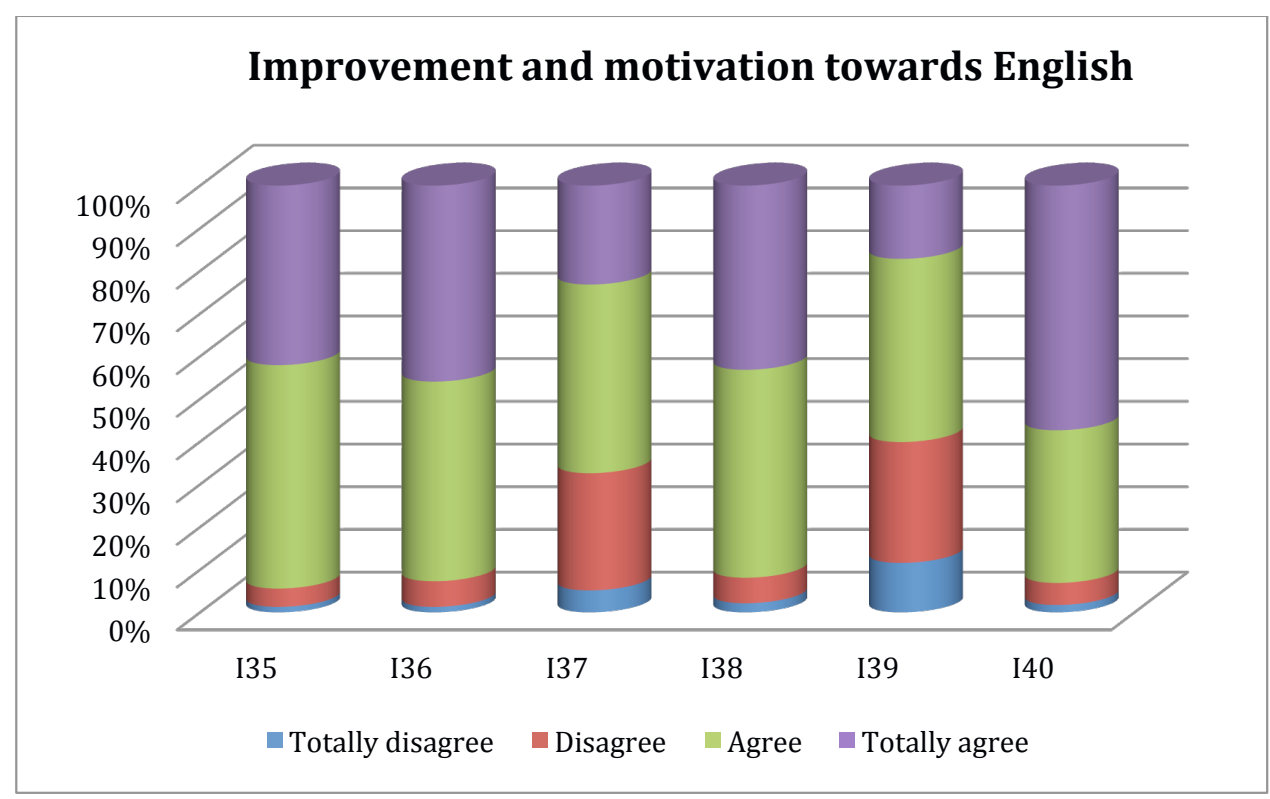

Figure 7. Percentage of parent perspectives on each of the items considered (35-40) in improvement and motivation towards English

\subsection{Within-cohort comparison}

If statistically significant differences are considered within each cohort in terms of the identification variables (metaconcern 2 - objective 8), only a minor number of interesting findings emerge. Even though not numerous, the greatest number of within-cohort differences cluster around two main variables: offspring education level and level of completed studies by parents. No significant differences at all are discerned for gender, and only meager differences can be traced within the age variable.

When considering the children's education level (Primary or Secondary Education), parents whose children are in Primary Education are more capable than those of Secondary education to help them out with their homework. This confirms the fact that the demand of help from parents is significantly more challenging in Secondary education. This greater demand may well lead to less enthusiasm in the parents' view of materials and resources, for the latter think they are less interesting and innovative than what it is stated in Primary education, in which a higher price for those materials and resources, on the other hand, is manifested. As it could easily be expected in consideration of the students' education level and age, there is more mobility of students in Secondary than in Primary education, and the students' motivation towards English is higher, according to parents, in Secondary than in Primary education. 
Turning now to the level of completed studies by parents, our outcomes evince some noteworthy differences. Again, when it comes to helping out children in doing their homework, the level of completed studies exerts a direct and progressive-regressive influence on the degree to which they feel capable of doing so: parents with no qualifications and Primary education are the ones who feel least capable, followed by those with Secondary or Professional Diplomas, who in turn show less ability than parents with a three- or four-year Degree. Curiously enough, parents with PhD studies score less than the last two groups, and only above the first one. There are also significant differences in the understanding that English is orally assessed, for in general terms parents with lower qualifications tend to think that English is assessed orally in a lower ratio. Even more significant are the differences between parents with no qualifications at all and the rest of the subgroups with other qualifications as regards mobility: the former score is significantly lower than the rest in the understanding that exchange/linguistic programs are beneficial to their offspring, and in the motivation they exert to participate in them. Finally, the higher education qualifications parents have, the higher their own motivation is towards learning English.

\section{Conclusion}

The present article has provided an overview of the language policies which have been implemented in Andalusia, where plurilingual education strives to consolidate itself. In such an attempt the principles and recommendations contained in the APPP and the PEDLA are of utmost importance, and as a matter of fact have been welcomed as "a major step forward" (Tobin and Abello-Contesse, 2013: 224) in advancing towards the bilingual mindset promoted by the Andalusian administration. Other sources from the specialized literature have been included to set the tenets of CLIL, though different questions, supported by prior investigations, have been raised as to whether these are actually being substantiated in Andalusian bilingual programs. Following the premise that parents' feedback can cast light upon some of the methodological controversies surrounding CLIL, as well as upon a possible mismatch between theory and practice, this study has strived to point out through location triangulation (Primary and Secondary school settings in Andalusia) the directions in which Andalusian plurilinguistic policies, embodied in the aforementioned APPP and PEDLA, could be improved.

In parents' eyes, to begin with, CLIL programs seem indeed to be exerting positive effects on students' language level and motivation, interest, and participation within the bilingual classroom. Their views are also positive as regards the ongoing assessment and plurality of student-centered methodologies at stake, including the acquisition of vocabulary, which in other studies yielded outstanding lacunae (Lancaster, 2016; Pérez Cañado 2016a, 2016c). Materials and resources are also assessed, if not enthusiastically, within reasonable means, though they would definitely benefit, according to the stakeholders surveyed, from including further guidelines in Spanish for parents. Mobility plays an important role in furthering bilingual programs, though there seems to be a gap between parents' theoretical enthusiasm and the figures for real mobility, which are significantly lower. Probing the economic, organizational, motivational or emotional reasons for such a mismatch, something of relevance to both academics and administrators, would bolster such a generally-agreed trigger for bilingualism. 
A main conclusion can be drawn from the comparison of the rest of the variables and items within them: while parents are optimistic about students and teachers, their self-appraisal does not show such a pretty picture, which may ultimately show that the measures taken to get them involved in the bilingual programs are not sufficient. Thus, they seem to struggle to offer their offspring extramural support at home, especially in Secondary education; while they hold in high esteem teachers' training, they believe their information about CLIL principles and the APPP is not enough; and while they think their sons and daughters have greatly improved in their use of English and are more motivated, they show lower levels of motivation and admit that the communication with teachers to track their children's progress should be more fluid.

The level of completed studies by parents has proved to be the most relevant within-cohort variable. In this sense, parents with higher educational qualifications show higher levels of assurance in the extramural support they can offer to their children; are more confident as regards the implementation of a plurality of assessment procedures, which includes oral assessment; and believe not only that mobility through exchange/linguistic programs is beneficial, but that they should motivate their children to enroll in them.

The present study has corroborated, with empirical evidence, that CLIL in Andalusia has taken solid and far-reaching steps. It has also evinced, though, that there is still considerable room for improvement, on different fronts and for different stakeholders, including parents. Further investigation and replication of this type of study may shed light on the direction in which governing policies should point in order to overcome the difficulties in the ongoing process towards functional bilingualism in Andalusia.

\section{REFERENCES}

Banegas, D. L. (2012). "CLIL teacher development: Challenges and experiences", in Latin American Journal of Content and Language Integrated Learning, 5, 1: 46-56.

Breidbach, S. and Viebrock, B. (2012). "CLIL in Germany: Results from recent research in a contested field of education", in International CLIL Research Journal, 1, 4: 5-16.

Brown, J. D. (2001). Using surveys in language programs. Cambridge: Cambridge University Press.

Bruton, A. (2011). "Is CLIL so beneficial, or just selective? Re-evaluating some of the research", in System, 39: 523-532.

Bruton, A. (2013). "CLIL: Some of the reasons why ... and why not", in System, 41: 587-597.

Brüning, C. I. and Purrmann, M. S. (2014). "CLIL pedagogy in Europe: CLIL teacher education in Germany", in Utrecht Studies in Language and Communication, 27: 315-338.

Cabezas Cabello, J. M. (2010). "A SWOT analysis of the Andalusian Plurilingualism Promotion Plan (APPP)", in M. L. Pérez Cañado (ed.), Proceedings of the 23rd GRETA Convention. Jaén: Joxman, 83-91.

Casal, S. and Moore, P. (2008). "The Andalusian bilingual sections scheme: Evaluation and consultancy", in International CLIL Research Journal, 1, 1: 36-46.

Cenoz, J., Genesee, F. and Gorter, D. (2013). "Critical analysis of CLIL: Taking stock and looking forward", in Applied Linguistics, 2013: 1-21.

Coyle, D. (2010). "Foreword". In D. Lasagabaster and Y. Ruiz de Zarobe (eds.), CLIL in Spain: Implementation, results and teacher training. Newcastle-upon-Tyne: Cambridge Scholars Publishing, vii-viii. 
Cummins, J. (2000). Immersion education for the millennium: What we have learned from 30 years of research on second language immersion. Available from $<$ http://www.iteachilearn. com/cummins/immersion2000.html>. [Accessed 01/06/2017].

Czura, A. and Papaja, K. (2013). "Curricular models of CLIL education in Poland", in International Journal of Bilingual Education and Bilingualism, 16, 3: 321-333.

Denzin, N. K. (ed.) (1970). Sociological methods: A source book. Chicago: Aldine.

Jäppinen, A. K. (2006). "CLIL and future learning", in S. Björklund, K. Mård-Miettinen, M. Bergström and M. Södergård (eds.), Exploring dual-focussed education. Integrating language and content for individual and societal needs, Available from <http://www.uwasa. fi/materiaali/pdf/isbn_952-476-149-1.pdf>. [Accessed 01/06/2017].

Junta de Andalucía (2005). Plan de Fomento del Plurilingüismo en Andalucía [Andalusian Plan for the Promotion of Plurilingualism]. Sevilla: Junta de Andalucía. Available from <http:// www.juntadeandalucia.es/boja/boletines/2005/65/d/5.html $>$ [Accessed 01/06/2017].

Junta de Andalucía (2017). Plan Estratégico de Desarrollo de las Lenguas en Andalucía [Strategic Plan for the Development of Languages in Andalusia]. Available from <http://www. juntadeandalucia.es/educacion/webportal/abaco-portlet/content/462f16e3-c047-479f-a7531030bf16f822> [Accessed 01/06/2017].

Lancaster, N. (2016). "Stakeholder perspectives on CLIL in a monolingual context", in English Language Teaching, 9, 2: 148-177.

Lasagabaster, D. and Doiz, A. (2016). "CLIL students' perceptions of their language learning process: Delving into self-perceived improvement and instructional preferences", in Language Awareness, 25, 1-2: 110-126.

Lewis, M. (1993). The Lexical Approach: The state of ELT and the way forward. Hove: Language Teaching Publications.

Liberali, F. (2013). "Student-teachers and teacher-educators experience new roles in pre-service bilingual teacher education in Brazil", in C. Abello-Contesse, P. M. Chandler, M. D. López-Jiménez and R. Chacón-Beltrán (eds.), Bilingual and multilingual education in the 21st century. Building on experience. Bristol: Multilingual Matters, 231-255.

Lorenzo, F. (2007). "The sociolinguistics of CLIL: Language planning and language change in 21st century Europe", in RESLA, 1: 27-38.

Lorenzo, F. (2010). "CLIL in Andalusia”. In D. Lasagabaster and Y. Ruiz de Zarobe (eds.), CLIL in Spain: Implementation, results and teacher training. Newcastle-upon-Tyne: Cambridge Scholars Publishing, 2-11.

Lorenzo, F., Casal, S. and Moore, P. (2009). "The effects of Content and Language Integrated Learning in European education: Key findings from the Andalusian bilingual sections evaluation project", in Applied Linguistics, 31, 3: 418-442.

Lorenzo, F., Casal, S., Moore, P. and Afonso, Y. M. (2009). Bilingüismo y educación. Situación de la red de centros bilingües en Andalucía. Sevilla: Fundación Centro de Estudios Andaluces.

Marsh, D., Maljers, A. and Hartiala, A. K. (2001). Profiling European CLIL classrooms. Languages open doors. Jyväskylä: University of Jyväskylä.

Marsh, D. (2015). "Postscript". In D. Marsh, M. L. Pérez Cañado and J. Ráez Padilla (eds.), CLIL in action: Voices from the classroom. Newcastle-upon-Tyne: Cambridge Scholars Publishing, 188-191.

Mehisto, P. and Asser, H. (2007). "Stakeholder perspectives: CLIL programme management in Estonia", in International Journal of Bilingual Education and Bilingualism, 10, 5: 683-701.

Michavila, F. (2009). "Preface", in M. L. Pérez Cañado (ed.), English language teaching in the European Credit Transfer System: Facing the challenge. Frankfurt am Main: Peter Lang, 9-16. 
Paran, A. (2013). "Content and language integrated learning: Panacea or policy borrowing myth?", in Applied Linguistics Review, 4, 2: 317-342.

Patton, M. Q. (1987). How to use qualitative methods in evaluation. London: Sage.

Pavón Vázquez, V. and Rubio, F. (2010). “Teachers' concerns and uncertainties about the introduction of CLIL programmes", in Porta Linguarum, 14: 45-58.

Pérez Cañado, M. L. (2012). "CLIL research in Europe: Past, present and future", in International Journal of Bilingual Education and Bilingualism, 15, 3: 315-341.

Pérez Cañado, M. L. (2015). "Training teachers for plurilingual education: A Spanish case study", in D. Marsh, M. L. Pérez Cañado and J. Ráez Padilla (eds.), CLIL in action: Voices from the classroom. Newcastle-upon-Tyne: Cambridge Scholars Publishing, 165-187.

Pérez Cañado, M. L. (2016a). "Are teachers ready for CLIL? Evidence from a European study", in European Journal of Teacher Education, 39, 2: 202-221.

Pérez Cañado, M. L. (2016b). "Evaluating CLIL programmes: Instrument design and validation", in Pulso. Revista de Educación, 39: 79-112.

Pérez Cañado, M. L. (2016c). "Teacher training needs for bilingual education: In-service teacher perceptions", in International Journal of Bilingual Education and Bilingualism, 19, 3: 266-295.

Tobin, N. A. and Abello-Contesse, C. (2013). "The use of native assistants as language and cultural resources in Andalusia's bilingual schools", in in C. Abello-Contesse, P. M. Chandler, M. D. López-Jiménez and R. Chacón-Beltrán (eds.), Bilingual and multilingual education in the 21st century. Building on experience. Bristol: Multilingual Matters, 231-255.

Wolff, D. (2002). "On the importance of CLIL in the context of the debate on plurilingual education in the European Union", in D. Marsh (ed.), CLIL/EMILE. The European dimension. Actions, trends, and foresight potential. Jyväskylä: University of Jyväskylä, 47-48.

\section{ACKNOWLedgements}

This work was supported by the Spanish Ministry of Economy and Competitiveness, under Grant FFI2012-32221, and by the Junta de Andalucía, under Grant P12-HUM-23480. 